\title{
PERSEPSI MAHASISWA UNIVERSITAS AL ASYARIAH MANDAR TERHADAP PESAN BAHAYA MEROKOK PADA KEMASAN ROKOK
}

\author{
Muh. Misraj Majid', Muhammad Massyat ${ }^{2}$, Masyhadiah ${ }^{3}$ \\ ${ }^{1}$ Prodi Ilmu Komunikasi, Fakultas Ilmu Sosial dan Ilmu Pemerintahan \\ Universitas Al Asyariah Mandar \\ Email: misrajisra@gmail.com \\ ${ }^{2}$ Prodi Ilmu Komunikasi, Fakultas Ilmu Sosial dan Ilmu Pemerintahan \\ Universitas Al Asyariah Mandar \\ Email: achatwibowo@gmail.com \\ ${ }^{2}$ Prodi Ilmu Komunikasi, Fakultas Ilmu Sosial dan Ilmu Pemerintahan \\ Universitas Al Asyariah Mandar \\ Email: masyhadiah22asraruddin@gmail.com
}

\begin{abstract}
This study aims to determine how the perception of Al-Asyariah Mandar University students towards the message of the dangers of smoking on cigarette packaging. The research used is descriptive qualitative to describe studying and understanding the attitudes, views, and behavior of individuals or groups. The results obtained are several active and passive smoker informants support the provision of warning images on cigarette packaging. But there are also those who think it's normal because they have never seen anything in person or confessions from people who have felt the bad effects like what happened in the picture on the cigarette package. Some informants saw that the warning pictures of the dangers of smoking gave them past experiences that could be a factor in forming their perceptions in the future.
\end{abstract}

\section{ABSTRAK}

Penelitian ini bertujuan untuk mengetahui bagaimana persepsi mahasiswa Univrsitas Al-Asyariah Mandar terhadap pesan bahaya merokok pada kemasan rokok. Penelitian yang digunakan adalah deskriptif kualitatif untuk menggambarkan menelaah dan memahami sikap, pandangan, dan perilaku individu atau kelompok. Hasil yang diperoleh adalah beberapa informan perokok aktif dan pasif mendukung pemberian gambar peringatan pada kemasan rokok. Namun ada juga yang menganggapnya biasa saja sebab tidak ada yang pernah betulbetul mereka lihat secara langsung atau pengakuan dari orang yang sudah merasakan dampak buruk seperti yang terjadi pada 
gambar pada kemasan rokok. Beberapa informan melihat bahwa gambar peringatan bahaya merokok memberikan mereka pengalaman masa lalu yang bisa menjadi faktor terbentuknya persepsi mereka pada masa yang akan datang.

Kata Kunci: Rokok, Kemasan Rokok, Bahaya Rokok.

\section{PENDAHULUAN}

Label peringatan kesehatan pada produk rokok merupakan alat yang paling hemat biaya dan cukup efektif untuk mendidik masyarakat, baik perokok maupun non-perokok, mengenai resiko kesehatan dari aktifitas merokok.

Dalam tinjauan komunikasi, peringatan kesehatan pada produk rokok merupakan bagian dari cara pembentukan wacana. Subjek (pembuat) pesan memproduksi wacana melalui isi pesannya untuk mempengaruhi pikiran orang banyak. Melalui wacana dalam peringatan dibungkus rokok tersebut, subjek (pembuat) wacana hendak mempengaruhi budaya dalam hal prilaku hidup sehat dan prilaku merokok yang berlangsung di tengah masyarakat (Hamdan, 2019).

Berbagai teori dalam psikologi sosial dan kesehatan, didukung oleh beragam studi empiris, telah menunjukkan keunggulan dari penggunaan gambar dan citra visual dibanding dengan pesan teks saja dalam proses komunikasi. Sejak tahun 1950-an banyak hasil penelitian menunjukan bahwa daya tarik akan ketakutan tergolong efektif untuk memotivasi perubahan perilaku hidup sehat (misalnya berhenti merokok). Terutama jika disandingkan dengan informasi tentang bagaimna menghindari konsekuensi menakutkan dari merokok. (www.hellosehat.com)

itulah sebabnya mengapa kurang lebih 40 negara di dunia telah memperkenalkan peringatan bergambar menyeramkan bahaya merokok di setiap bungkusan rokok, dimulai dengan kanada pada tahun 2001. Di negaranegara ASEAN, empat dari 11 negara telah menerapkan peringatan kesehatan berbentuk gambar pada kemasan rokoknya sejak tahun 2004 yang di awali di singapura. Di Indonesia, aturan untuk mencamtumkan gambar peringatan bahaya merokok telah berjalan sejak Juni 2014. (www.hellosehat.com)

Di kutip dari WHO, bukti dampak potensial yang lebih besar dari peringatan bergambar berasal dari beragam studi dan wawancara, termasuk pula studi eksperimen dan survei berbasis populasi di kalangan perokok Kanada, Australia, Belanda, New Zealand, Mexiko, Malaysia, Thailand. (www.hellosehat.com) 
Merujuk pada salah satu penelitian yang diadakan di kanada oleh David Hammond dan tim penelitinya, dilansir dari American Journal of Public Health, seperlima dari total 616 partisipasian melaporkan pengurangan aktivitas merokok sebagaai akibat dari paparan terhadap gambar peringatan di bungkus rokok, dan hanya $1 \%$ dari mereka yang melaporkan malah semakin giat merokok. Meskipun keseluruhan keseluruhan peserta melaporkan mengalami respon negatif terhadap peringatan bahaya merokok. (www.hellosehat.com)

Termasuk rasa takut (44\%) dan jijik $(58 \%)$, perokok yang melaporkan dampak emosional negatif yang lebih besar lebih mungkin untuk berhenti, mencoba berhenti, atau mengurangi porsi merokok mereka tiga bulan kemudian. Partisipan yang memilih untuk menghindar memperhatikan peringatan gambar (30\%) dilaporkan cenderung kurang menunjukan kesadaran akan risiko kesehatan atau menunjukan keinginan terlibat dalam perilaku berhenti merokok. (www.hellosehat.com)

Dilansir dari National Geographic Indonesia, berdasarkan data riset kesehatan dasar 2013, perokok aktif mulai dari usia 10 tahun ke atas berjumlah 58.750 .592 orang $(36 \%)$ dari total populasi), alias sepuluh kali lipat dari total penduduk Singapura. (www.hellosehat.com)

Ironisnya, semenjak aturan peringatan bahaya merokok menggunakan visualisasi gambar mengerikan diberlakukan di pasar Indonesia, antara news melaporkan Indonesia di nobatkan sebagai negara dengan jumlah perokok terbanyak se-Asia Tenggara dengan jumlah perokok aktif mencapai 51,1 persen dari total penduduknya. (antaranews.com)

Selain itu menurut The Jakarta post, saat ini Indonesia masih menduduki peringkat keempat dalam total jumlah peokok terbanyak, mengikuti China, Rusia, dan Amerika serikat, sekaligus juga menempati peringkat pertama dengan jumlah perokok aktif pria dewasa di atas usia 15 tahun terbanyak di dunia: mencapai 67,4 persen total penduduk. (www.jakartapost.com)

Di lansir dari DW, dengan rata-rata komsumsi rokok bisa mencapai 1,085 batang per kepala setiap tahunnya, angka perokok aktif di Indonesia justru yakini akan naik menjadi 90 juta orang pada tahun 2025. (www.dw.com)

Secara umum, grafis peringatan bahaya merokok di bungkus rokok menunjukan bahwa visualisasi menyeramkan ini: (1) lebih diperhatikan dari pada peringatan yang hanya mencamtumkan teks saja, (2) lebih efektif untuk mendidik perokok tentang resiko kesehatan dari merokok dan juga meningkatkan sugesti alam bawah sadar mereka mengenai risiko kesehatannya, dan (3) terkait dengan peningkatan motivasi untuk berhenti merokok.

Walaupun begitu gambar-gambar menyeramkan nan realistis ini, paruparu membusuk, kanker mulut ganas dengan tampilan gigi dan gusi yang 
hancur total, hingga gambar tengkorak, dianggap sebagian orang bisa menjadi senjata makan tuan untuk pemerintah dalam menggalakkan kampanye berhenti merokok. Adalah gambar peringatan bahaya peringatan pada kemasan rokok dimana bisa membuat seseorang akan sadar dengan kesehatannya yang bisa menimbulkan kanker, serangan jantung dan gangguan kehamilan bagi wanita.

Menurut sebuah studi terbaru dari Universitas of Illions tahun 2016 dilansir dari Journal Now, peringatan itu di pandang oleh banyak pihak sebagai ancama atas kebebasan, pilihan atau otonomi, sehingga mereka bertindak secara naluriah untuk melawan peringatan itu.

Mahasiswa kedokteran yang terlibat dalam studi tersebut. Menurut Nicole Lovoie, gambar peringatan ini justru membuat orang-orang merasa marah, bukan hanya takut, dan merasa di bohongi karena kenyataannya jauh berbeda seperti apa yang ada di gambar tersebut, berdasarkan pengalaman orang di sekitar dan/atau apa yang mereka alami sendiri. (www.dw.com)

Brian Quick, salah satu peneliti yang terlibat dalam studi tersebut, lebih lanjut mengatakan bahwa, beberapa individu tidak hanya akan bereaksi negatif terhadap potensi ancaman terhadap kebebasan mereka, namun mereka akan lebih mungkin untuk melakukan hal yang di larang, dalam hal ini merokok untuk membuktikan pemberontakan mereka terhadap ancaman tersebut. (www.dw.com)

Menurut para peneliti, jika seseorang sudah memilih untuk merokok, mereka akan sukarela untuk mempedulikan gambar-gambar yang tercantum di bungkus rokok mereka.

Walaupun bukti angka penurunan rata-rata perokok di berbagai belahan dunia tidak biasa di pungkiri, Lavoie berpendapat bahwa penurunan tersebut lebih dipengaruhi oleh kenaikan pajak dan bea cukai rokok.

Dalam gambar kemasan rokok juga berbeda dari sebagian orang akan jijik melihat gambar tersebut sehingga mempengaruhi minat seorang perokok untuk membeli, Oleh karena itu, peneliti tertarik meneliti persepsi mahasiswa Universitas Al Asyariah Mandar terhadap pesan bahaya merokok pada kemasan rokok.

\section{METODE PENELITIAN}

Penelitian ini menggunakan metode kualitatif yaitu penelitian yang memanfaatkan wawancara terbuka untuk menelaah dan memahami sikap, pandangan, perasaan, dan perilaku individu atau sekelompok orang (Moleong, 2011:11). Sedangkan di tinjau dari jenisnya, penelitian menggunakan deskriptif 
ualitatif yaitu data yang di kumpulkan berupa kata-kata, bukan angka dan kutipan data untuk memberi gambaran penyajian laporan.

Teknik pengumpulan data dilakukan dengan beberapa cara, yakni; (1) observasi, dilakukan untuk memperoleh informasi tentang kelakuan manusia seperti terjadi dalam kenyataannya. dengan observasi ini dapat diperoleh gambaran yang lebih jelas dan menggali data tentang bagaimana persepsi mahasiswa terhadap pesan bahaya meroko pada kemasan rokok; (2) wawancara, mengumpulkan data atau informasi dengan cara langsung bertatap muka dengan informan agar mendapatkan data lengkap dan mendalam, pengambilan data dengan metode ini melalui proses tanya jawab kepada informan yang dilakukan secara sistematis dan berdasarkan pada tujuan penelitian; (3) dokumentasi, melacak data-data dari berbagai sumber tertulis dan merekam berbagai peristiwa yang relevan di lapangan.

\section{HASIL PENELITIAN}

\section{Tahap Stimulation}

Tahap stimulus ini, merupakan tahap responden menerima rangsangan, dimana responden melihat dan mengetahui peringatan bahaya merokok pada kemasan rokok. Wawancara dilakukan dengan bentuk pertanyaan mengenai apakah mahasiswa mengetahui adanya peringatan bahaya merokok pada kemasan rokok. Salah satu informan atas nama Wahyu Nugraha menjawab pertanyaan peneliti sebagai berikut;

"Ya, saya mengetahui adanya peringatan bahaya merokok bahkan peringatan tersebut sangat terlihat dengan jelas dalam kemasan rokok". (Wawancara, 11 November 2019)

Kemudian pertanyaan selanjutnya mengenai makna dari adanya peringatan tersebut, dengan bentuk pertanyaan apa makna yang mahasiswa tangkap dari adanya peringatan bahaya merokok pada kemasan rokok, salah satu informan atas nama Ilham menjawab pertanyaan peneliti sebagai berikut;

"Makna peringatan bahaya merokok tersebut adalah bahwa peringatan tersebut menjelaskan bahwa menkonsumsi rokok sebenarnya tidak baik untuk kesehatan dan dapat menimbulkan berbagai macam penyakit seperti yang tertera dalam peringatan pada kemasan rokok". (Wawancara, 11 November 2019)

Selanjutnya wawancara di lanjutkan dengan Sahril yang memberikan informasi tentang apakah mengetahui adanya peringatan bahaya merokok pada kemasan rokok. Adapun hasil wawancara dengan mahasiswa atas nama Sahril adalah sebagai berikut; 
"Ya betul, saya sering melihat peringatan tersebut pada setiap kemasan rokok". (Wawancara, 11 November 2019)

Kemudian peneliti memberikan pertanyaan mengenai makna yang ditangkap dari adanya peringatan tersebut pada kemasan rokok ke salah satu informan bernama Suaib. Berikut hasil wawancara dari mahasiswa atas nama Suaib;

"Menurut saya makna peringatan tersebut untuk menginformasikan kepada khalayak bahwa merokok dapat menyebabkan berbagai banyak penyakit seperti kanker, paru-paru, serangan jantung dan gangguan kehamilan dan janin pada wanita". (Wawancara, 11 November 2019)

Selanjutnya peneliti mewancarai salah satu informan atas nama Reno, yang menginformasika apakah mahasiswa tersebut mengetahui peringatan bahaya merokok pada kemasan rokok. Adapun hasil wawancara dari mahasiswa tersebut adalah sebagai berikut;

"Ya benar, saya melihat peringatan bahaya merokok pada setiap kemasan rokok. Walaupun terkadang saya mengabaikan pesan peringatan tersebut". (Wawancara, 12 November 2019)

Kemudian peneliti mewancarai salah satu informan bernama Abdullah mengenai makna yang di tangkap dari adanya peringatan bahaya merokok pada kemasan rokok. Adapun hasil wawancara tersebut adalah sebagai berikut;

"Menurut saya, makna peringatan bahaya merokok pada kemasan rokok tersebut yaitu memberitahu kepada masyarakat bahwa merokok itu tidak baik bagi kesehatan karena dapat menyebabkan banyak penyakit akibat rokok seperti pesan peringatan yang tertera pada setiap kemasan rokok". (Wawancara, 12 November 2019)

Berikutnya peneliti mewawancarai salah satu informan bernama Nirwan, mengenai apakah mahasiswa tersebut mengetahui peringatan bahaya merokok pada setiap kemasan rokok.

"Ya, saya mengetaui dan sering melihat pada peringatan bahaya merokok di setiap kemasan rokok". (Wawancara, 12 November 2019)

Kemudian peneliti mewawancarai salah satu informan atas nama Eko Wardana. Peneliti memberi pertanyaan mengenai makna yang ditangkap dari adanya peringatan tersebut. Adapun hasil wawancara dari mahasiswa tersebut adalah sebagai berikut;

"Menurut saya, makna dari adanya peringatan bahaya merokok pada kemasan rokok adalah bahwa merokok itu tidak baik bagi kesehatan karena dapat menyebabkan banyak penyakit yang berbahaya". (Wawancara, 12 November 2019) 
Selanjutnya peneliti mewancarai salah satu informan bernama Muhammad Dery Rifani. Peneliti memberi pertanyaan mengenai apakah mahasiswa tersebut mengetahui adanya peringatan bahaya merokok. Adapun hasil wawancara dari mahasiswa tersebut adalah sebagai berikut;

"Ya saya sering melihat gambar atau peringatan bahaya merokok pada kemasan rokok. Walau peringatan dan gambar yang tertera cukup menyeramkan,namun kebiasaan merokok tetap saya tidak bisa tinggalkan". (Wawancara, 13 November 2019)

Kemudian peneliti mewawancarai salah satu informan bernama Sudirman. Peneliti memberi pertanyaan mengenai makna yang telah di tangkap dari adanya peringatan bahaya merokok pada kemasan rokok. Adapun hasil wawancara dari mahasiswa tersebut adalah sebagai berikut;

"Makna yang saya tangkap dari adanya peringatan bahaya merokok tersebut adalah bahwa merokok dapat menyebabkan penyakit berbahaya seperti kanker, paru-paru, serangan jantung dan gangguan kehamilan pada wanita". (Wawancara, 13 November 2019)

\section{Tahap Organization}

Tahap ini adalah tahap dimana informan setelah melihat adanya rangsangan dapatkah informan tersebut mengorganisasikan berdasarkan tatanan tertentu sesuai dengan rangsangan yang didapat.

Hasil wawancara dengan informan bernama Hermansya, mengenai harapan dari pihak pencantum peringatan tersebut pada setiap kemasan rokok dan apakah mahasiswa tersebut mempertimbangkan untuk berhenti merokok setelah melihat adanya peringatan tersebut dan apakah dalam melakukan kebiasaan merokok dilakukan secara reflek. Adapun hasil wawancara dari mahasiswa tersebut adalah sebagai berikut;

"Menurut saya harapan dari pihak pencantum adalah agar para perokok berhenti merokok. Tapi saya tidak mempertimbangkan untuk berhenti merokok setelah melihat peringatan tersebut. Dan saya reflek dalam melakukan kebiasaan rokok begitu saja". (Wawancara, 14 November 2019)

Selanjutnya peneliti mewawancarai salah satu informan bernama Musmulyanis. Peneliti memberi pertanyaan kepada mahasiswa tersebut mengenai apa harapan dari pihak pencantum peringatan tersebut pada setiap kemasan rokok, kemudian memberi pertanyaan mengenai apakah mempertimbangkan untuk berhenti merokok setelah melihat adanya peringatan tersebut, pertanyaan berikutnya mengenai apakah melakukan kebiasaan merokok dilakukan secara reflek. Adapun hasil wawancara adalah sebagai berikut; 
"Ya tentunya harapan dari pihak pencantum yakni masyarakat atau khalayak yang merokok untuk berhenti merokok. Kalau untuk mempertimbangkan tidak merokok setelah melihat peringatan tersebut, saya fikir tidak. Apalagi kebiasaan merokok ini, sudah kebiasaan. Jadi setiap kebiasaan merokok semua dilakukan secara reflek atau spontan". (Wawancara, 14 November 2019)

Kemudian peneliti mewawancarai salah satu informan bernama Yohanes. Peneliti memberi pertanyaan kepada informan tersebut mengenai apa harapan dari pihak pencantum peringatan tersebut pada setiap kemasan rokok, kemudian pertanyaan mengenai apakah mempertimbangkan untuk berhenti merokok setelah melihat adanya peringatan tersebut, pertanyaan selanjutnya mengenai apakah dalam melakukan kebiasaan merokok dilakukan secara reflek. Adapun hasil wawancara adalah sebagai berikut;

"Harapan dari pihak pencantum yakni agar khalayak yang merokok untuk berhenti merokok. Kalau saya pribadi setelah melihat peringatan tersebut, saya belum bisa meninggalkan kebiasaan merokok saya. Karena sudah sangat kebiasaan dengan merokok, jadi semua di lakukan secara reflek begitu saja". (Wawancara, 14 November 2019)

Selanjutnya peneliti mewawancarai salah satu informan bernama Jusman. Peneliti memberi pertannyaan kepada informan tersebut mengenai apa harapan dari pihak pencantum peringatan tersebut pada setiap kemasan rokok, kemudian pertanyaan mengenai apakah mempertimbangkan untuk berhenti merokok setelah melihat adanya peringatan tersebut, pertanyaan berikutnya mengenai apakah dalam melakukan kebiasaan merokok dilakukan secara reflek. Adapun hasil wawancara adalah sebagai berikut;

"Tentunya adanya peringatan pada setiap kemasan rokok yaitu agar para khalayak untuk berhenti merokok. Saya sendiri setelah melihat peringatan pada kemasan rokok, saya belum berfikir untuk berhenti merokok. Dan kalau merokok ini merupakan kebiasaan saya, jadi ketika saya merokok semua saya lakukan secara spontan". (Wawancara, 15 November 2019)

Kemudian peneliti mewawancarai salah satu informan bernama Bistari. Peneliti memberi pertannyaan kepada informan tersebut mengenai apa harapan dari pihak pencantum peringatan tersebut pada setiap kemasan rokok, kemudian pertanyaan mengenai apakah mempertimbangkan untuk berhenti merokok setelah melihat adanya peringatan tersebut, pertanyaan berikutnya mengenai apakah dalam melakukan kebiasaan merokok dilakukan secara reflek. Adapun hasil wawancara adalah sebagai berikut;

"Mungkin harapan dari pihak pencantum peringatan tersebut yakni agar berkurangnya perokok pada khalayak umum. Saya sendiri belum dapat 
memutuskan untuk berhenti merokok walaupun saya telah sering melihat peringatan tersebut pada setiap kemasan rokok. Saya lakukan kebiasaan merokok secara reflek atau spontan. (Wawancara, 14 November 2019)

\section{Tahap Interpretation dan Evaluation}

Tahap ini merupakan tahap dimana informan membuat penafsiran dan evaluasi terhadap stimuli atau rangsangan tersebut.

Pada tahap ini peneliti telah mewawancarai salah satu informan bernama Mustafa, mengenai bagaimana pengetahuan mahasiswa tersebut tentang bahaya penyakit akibat merokok pada setiap kemasan rokok, kemudian peneliti memberi pertanyaan mengenai apakah informan tersebut takut dengan adanya gambar-gambar bentuk penyakit yang diakibatkan oleh kebiasaan merokok yang tertera pada setiap kemasan rokok. Adapun hasil wawancara dari informan tersebut adalah sebagai berikut;

"Menururt saya peringatan tersebut tidak benar, karena selama saya melakukan kebiasaan merokok, saya tidak pernah mengalami penyakit yang berbahaya seperti pada peringatan tersebut. Saya juga tidak takut dengan bentuk gambar penyakit akibat merokok tersebut karena gambar penyakit tersebut terlalu dibuat-buat tidak sesuai dengan kenyataan yang ada. (Wawancara, 16 November 2019)

Selanjutnya peneliti telah mewawancarai salah satu informan bernama Ramli Tamrin mengenai bagaimana pengetahuan mahasiswa tersebut tentang bahaya penyakit akibat merokok pada setiap kemasan rokok, kemudian peneliti memberi pertanyaan mengenai apakah informan tersebut takut dengan adanya gambar-gambar bentuk penyakit yang diakibatkan oleh kebiasaan merokok yang tertera pada setiap kemasan rokok. Adapun hasil wawancara dari informan tersebut adalah sebagai berikut;

"Menurut saya, saya tidak pernah merasakan adanya efek bahaya selama saya merokok, jadi peringatan bahaya merokok yang ada pada setiap kemasan rokok itu tidak benar adanya. Dan saya tidak takut dengan bentuk gambar penyakit akibat merokok tersebut karena itu (Wawancara, 16 November 2019)

Selanjutnya peneliti telah mewawancarai salah satu informan bernama Ramdan mengenai bagaimana pengetahuan mahasiswa tersebut tentang bahaya penyakit akibat merokok pada setiap kemasan rokok, kemudian peneliti memberi pertanyaan mengenai apakah informan tersebut takut dengan adanya gambar-gambar bentuk penyakit yang diakibatkan oleh kebiasaan merokok yang tertera pada setiap kemasan rokok. Adapun hasil wawancara dari informan tersebut adalah sebagai berikut; 
"Menurut saya, peringatan bahaya merokok pada setiap kemasan rokok terlalu didramatisir, karena efek yang saya rasakan selama mengkonsumsi rokok hanya batuk-batuk kecil yang menurut saya tidak berbahaya. Saya juga tidak takut dengan bentuk gambar penyakit akibat merokok tersebut karena gambar-gambar penyakit tersebut tidak sesuai dengan efek merokok". (Wawancara, 16 November 2019)

Selanjutnya peneliti telah mewawancarai salah satu informan bernama Mustakim mengenai bagaimana pengetahuan mahasiswa tersebut tentang bahaya penyakit akibat merokok pada setiap kemasan rokok, kemudian peneliti memberi pertanyaan mengenai apakah informan tersebut takut dengan adanya gambar-gambar bentuk penyakit yang diakibatkan oleh kebiasaan merokok yang tertera pada setiap kemasan rokok. Adapun hasil wawancara dari informan tersebut adalah sebagai berikut;

"Menurut saya, peringatan bahaya merokok pada kemasan rokok tidak benar adanya dan terlalu dibuat-buat, karena selama saya merokok tidak pernah terjadi penyakit seperti dalam peringatan yang ada pada setiap kemasan rokok. Saya tidak takut dengan bentuk gambar penyakit akibat merokok tersebut karena gambar-gambar penyakit tersebut hanya rekayasa untuk menakut-nakuti para perokok yang belum tentu dirasakan oleh para perokok". (Wawancara, 17 November 2019)

Selanjutnya peneliti telah mewawancarai salah satu informan bernama Ridwan mengenai bagaimana pengetahuan mahasiswa tersebut tentang bahaya penyakit akibat merokok pada setiap kemasan rokok, kemudian peneliti memberi pertanyaan mengenai apakah informan tersebut takut dengan adanya gambar-gambar bentuk penyakit yang diakibatkan oleh kebiasaan merokok yang tertera pada setiap kemasan rokok. Adapun hasil wawancara dari informan tersebut adalah sebagai berikut;

"Menurut saya, peringatan bahaya merokok pada kemasan rokok terlalu dibuat-buat tidak sesuai dengan kenyataan, karena bahaya merokok yang saya rasakan hanyalah batuk-batuk saja. Kalau mengenai rasa takut terhadap peringatan yang ada pada setiap kemasan rokok, saya tidak takut dengan peringatan dan bentuk gambar penyakit akibat merokok tersebut karena gambar-gambar penyakit tersebut hanya rekayasa untuk menakutnakuti saja". (Wawancara, 17 November 2019)

\section{Tahap Memory}

Pada tahap ini, informan setelah menerima stimuli atau rangsangan kemudian terekam oleh memori informan dan mengaitkan berdasarkan pengalaman masa lalu atau berdasarkan pengetahuan responden. 
Adapun hasil wawancara peneliti dengan informan bernama Wahyu Nugraha, mengenai apakah ada efek bahaya yang dirasakan selama merokok, kemudian peneliti memberi pertanyaan mengenai apakah peringatan bahaya merokok tersebut sesuai dengan efek yang dirasakan selama merokok. Berikut hasil wawancara peneliti dengan informan tersebut;

"Saya tidak pernah merasakan efek bahaya dari kebiasaan saya merokok selama ini. Menurut saya peringatan tersebut tidak sesuai dengan efek yang saya rasakan setelah selama ini merokok". (Wawancara, 18 November 2019)

Selanjutnya hasil wawancara peneliti dengan informan bernama Ilham, mengenai apakah ada efek bahaya yang dirasakan selama merokok, kemudian peneliti memberi pertanyaan mengenai apakah peringatan bahaya merokok tersebut sesuai dengan efek yang dirasakan selama merokok. Berikut hasil wawancara peneliti dengan informan tersebut;

"Saya tidak pernah merasakan efek bahaya selama saya mengkonsumsi rokok. Menurut saya peringatan tersebut tidak sesuai dengan efek merokok yang saya rasakan". (Wawancara, 18 November 2019)

Selanjutnya hasil wawancara peneliti dengan informan bernama Sahril, mengenai apakah ada efek bahaya yang dirasakan selama merokok, kemudian peneliti memberi pertanyaan mengenai apakah peringatan bahaya merokok tersebut sesuai dengan efek yang dirasakan selama merokok. Berikut hasil wawancara peneliti dengan informan tersebut;

"Saya tidak pernah merasakan efek bahaya merokok seperti peringatan tersebut karena hanya efek batuk dan sesak yang saya rasakan selama merokok. Menurut saya peringatan tersebut tidak sesuai dengan efek yang saya rasakan". (Wawancara, 18 November 2019)

Selanjutnya hasil wawancara peneliti dengan informan bernama Suaib, mengenai apakah ada efek bahaya yang dirasakan selama merokok, kemudian peneliti memberi pertanyaan mengenai apakah peringatan bahaya merokok tersebut sesuai dengan efek yang dirasakan selama merokok. Berikut hasil wawancara peneliti dengan informan tersebut;

"Saya tidak pernah merasakan efek bahaya merokok selama saya merokok. Menurut saya peringatan tersebut tidak sesuai dengan efek yang saya rasakan selama merokok". (Wawancara, 18 November 2019)

Selanjutnya hasil wawancara peneliti dengan informan bernama Reno, mengenai apakah ada efek bahaya yang dirasakan selama merokok, kemudian peneliti memberi pertanyaan mengenai apakah peringatan bahaya merokok tersebut sesuai dengan efek yang dirasakan selama merokok. Berikut hasil wawancara peneliti dengan informan tersebut; 
"Saya tidak pernah merasakan efek bahaya merokok seperti dalam peringatan tersebut karena efek yang saya sering rasakan hanyalah batuk saja. Menurut saya peringatan tersebut tidak sesuai dengan efek yang saya rasakan selama ini". (Reno, 19 November 2019)

\section{Tahap Recall}

Tahap ini merupakan tahap akhir dimana mahasiswa sebagai informan setelah menerima rangsangan atau stimuli dan telah di rekam dalam memori sesuai dengan pengalaman dan pengetahuan kemudian diungkapkan.

Adapun hasil wawancara peneliti dengan salah satu informan bernama Abdullah, mengenai pemikirannya terhadap peringatan bahaya merokok pada setiap kemasan rokok. Berikut hasil wawancara peneliti dengan informan tersebut;

"menurut saya peringatan bahaya merokok pada setiap kemasan rokok tersebut terlalu dibuat-buat tidak sesuai dengan realita yang ada". (Abdullah, 20 November 2019)

Berikutnya hasil wawancara peneliti dengan salah satu informan bernama Nirwan, mengenai pemikirannya terhadap peringatan bahaya merokok pada setiap kemasan rokok. Berikut hasil wawancara peneliti dengan informan tersebut;

"Menurut saya peringatan bahay merokok pada kemasan rokok tersebut hanya untuk menakut-nakuti para perokok yang belum tentu dirasakan oleh para perokok". (Nirwan, 20 November 2019)

Berikutnya hasil wawancara peneliti dengan salah satu informan bernama Eko Wardana, mengenai pemikirannya terhadap peringatan bahaya merokok pada setiap kemasan rokok. Berikut hasil wawancara peneliti dengan informan tersebut;

"Menurut saya peringatan bahaya merokok pada kemasan rokok tersebut terlalu dibuat-buat tidak sesuai dengan kenyataan sehingga saya sebagai perokok tetap saja akan terus merokok". (Eko Wardana, 20 November 2019)

Berikutnya hasil wawancara peneliti dengan salah satu informan bernama Muhammad Dery Rifani, mengenai pemikirannya terhadap peringatan bahaya merokok pada setiap kemasan rokok. Berikut hasil wawancara peneliti dengan informan tersebut;

"Menurut saya peringatan bahaya merokok pada kemasan rokok tersebut terlalu dibuat-buat tidak sesuai dengan kenyataan yang sebenarnya". (Muhammad Dery Rifani, 21 November 2019) 
Berikutnya hasil wawancara peneliti dengan salah satu informan bernama Sudirman, mengenai pemikirannya terhadap peringatan bahaya merokok pada setiap kemasan rokok. Berikut hasil wawancara peneliti dengan informan tersebut;

"Menurut saya peringatan bahaya merokok pada kemasan rokok tersebut terlalu dibuat-buat dan hanya untuk menakut-nakuti para perokok agar berhenti merokok". (Sudirman, 21 November 2019)

Penelitian ini bertujuan ingin mengetahui persepsi Mahasiswa Universitas Al Asyariah Mandar terhadap adanya peringatan bahaya merokok pada setiap kemasan rokok.

Peneliti melakukan wawancara terstruktur yang sudah dibuat beberapa pertanyaan oleh peneliti yang kemudian diberikan kepada informan untuk dijawab. Penelitian dilakukan selama bulan November 2019.

Pada penelitian ini, tahapan persepsi meliputi tahap Stmulation, Organization, Interpretation-Evaluation, Memory, dan Recall untuk mengetahui persepsi terhadap peringatan bahaya merokok pada setiap kemasan rokok.

Pada tahap Stimulation (rangsangan), semua informan mengetahui dengan jelas adanya label peringatan yang tercantum pada kemasan rokok dan perokok dapat memahami makna dari adanya label peringatan tersebut. Perokok memahami bahwa label tersebut menjelaskan rokok yang mereka konsumsi sebenarnya tidak baik untuk kesehatan dan dapat menimbulkan berbagai macam penyakit. Hal ini dapat disebabkan karena faktor perhatian sangat mempengaruhi persepsi. Sesuai dengan Kenneth E. Andersen yang menyatakan bahwa perhatian adalah proses mental ketika stimuli atau serangkaian stimuli menjadi menonjol dalam kesadaran pada saat stimuli melemah. (Jalaludin Rahmat : 2011). Yang berarti peringatan bahaya merokok tersebut sangat menonjol sehingga responden melihat peringatan bahaya merokok tersebut.

Pada dimensi Organization, pada tahapan yang kedua, semua informan paham bahwa harapan pencantuman label peringatan tersebut untuk menyadarkan para perokok kalau produk tersebut tidak baik untuk kesehatan sehingga para perokok mengurangi intensitasnya dalam mengkonsumsi rokok dan kalau bisa berhenti. Tetapi semua perokok tetap saja reflex untuk melakukan kebiasaannya merokok setelah mengetahui makna dari label dan harapan dari pencantuman label tersebut.

Pada dimensi Interpretation-Evaluation, pengetahuan perokok terhadap label peringatan bahaya merokok tidak lantas membuat para perokok untuk berhenti merokok, mereka tetap mengkonsumsi rokok karena pengalaman 
mereka menjelaskan bahwa mereka tidak pernah menderita akibat mengkonsumsi rokok. Selain itu informan juga menyatakan bahwa adanya bentuk gambar-gambar penyakit pada setiap kemasan rokok juga tidak membuat mereka takut, karena mereka beranggapan bahwa gambar-gambar penyakit tersebut hanya mengada-ada dan dibuat-buat tidak sesuai dengan efek merokok yang mereka rasakan.

Pada tahap ini dapat kita kaitkan dengan persepsi menurut Stephen P.Robbins bahwa persepsi sangat dipengaruhi oleh karakteristik pribadi individu tersebut. Karakteristik pribadi yang mempengaruhi persepsi meliputi sikap, keplribadian, motif, kepentingan, pengalaman masa lalu dan harapan. (Stephen p.Robbins : 2013)

Hal ini yang mungkin menyebabkan informan tidak takut dengan adanya peringatan merokok karena karakteristik pribadi individu yang berbeda-beda. Sesuai dengan wawancara dengan salah seorang yang menjadi sampel mengatakan bahwa ia tidak peduli dengan peringatan bahaya merokok tersebut, karena bahaya merokok yang tertera pada kemasan rokok tidak sesuai dengan bahaya yang dirasakan oleh individu tersebut. Kemudian informan yang lain mengatakan merokok yang dilakukan disebabkan oleh beberapa hal salah satunya untuk mengurangi stress dan melepas penat. Dari wawancara yang dilakukan dapat disimpulkan bahwa setiap pribadi individu mempunyai motif, kepentingan, kepribadian dan pengalaman masa lalu dan harapan yang berbeda-beda.

Pada tahap Memory, menurut informan, efek yang dirasakan mereka setelah selama ini merokok tidak sesuai dengan apa yang dijelaskan oleh label peringatan bahaya merokok yang tertera pada kemasan rokok. Sehingga para perokok berfikir dari pengalaman pribadi dan melihat realitas yang ada bahwa mengkonsumsi rokok tidaklah menyebabkan penyakit seperti yang dijelaskan pada label peringatan di kemasan. Selain itu hanya efek batuk-batuk dan sesak yang mereka rasakan selama merokok, jadi peringatan tersebut tidak sesuai denga kenyataan.

Hal ini juga dipengaruhi oleh karakteristik pribadi individu sesuai dengan faktor persepsi menurut Stephen P. Robbins. Namun dalam dimensi Memory ini lebih dipengaruhi oleh pengalaman masa lalu dari pribadi individu tersebut, karena banyak informan yang menyatakan tidak ada efek bahaya selama pengalamannya melakukan kebiasaan merokok. Dan informan juga menyatakan efek yang dirasakan selama merokok juga tidak sesuai dengan efek bahaya merokok yang tertera dalam peringatan bahaya merokok pada setiap kemasan rokok tersebut.

Pada tahap Recall, pemikiran individu informan yang mengganggap bahwa merokok tidak akan berbahaya bagi mereka, lalu mereka tetap 
melakukan kebiasaannya merokok. Mereka menganggap bahwa peringatan bahaya merokok yang tertera pada kemasan rokok itu hanya menakut-nakuti, dibuat-buat, mengada-ada, dan hanya rekayasa yang tidak sesuai dengan kenyataan.

\section{KESIMPULAN}

Kesimpulan yang dapat ditarik adalah bahwa makna yang konsumen letakkan pada stimulus dari label peringatan bahaya merokok yang mereka lihat dan pengalaman masa lalu menjadi faktor penting dalam pembentukan persepsi seseorang. Tidak ada persepsi yang bersifat objektif, karena masingmasing individu melakukan interpretasi berdasarkan pengalaman masa lalu dan kepentingannya. Persepsi merupakan suatu proses kognitif psikologis yang mencerminkan sikap, kepercayaan, nilai, dan pengharapan persepsi bersifat pribadi.

\section{SARAN}

Berdasarkan kesimpulan di atas peneliti mencatat beberapa saran, bagi pemerintah dan perusahaan seharusnya dalam membuat peraturan tentang pencamtuman peringatan bahaya merokok pada kemasan rokokn jangan setengah-setengah. Dan dalam pembuatan label seharusnya dipertimbangkan oleh pemerintah agar tujuan yang dipertimbangkan terwujud. Dan bagi peneliti mempertimbangkan hal lain yang berhubungan dengan pembentukan persepsi konsumen selain itu persepsi sebagai penambahan indicator format atau aturan pembuatan label atau iklan dalam tujuan mempersuasif konsumen.

\section{DAFTAR PUSTAKA}

Arifin, Anwar, 2011, ilmu komunikasi, sebuah pengaturan ringkas, Jakarta: perbit $\mathrm{CV}$ rajawali.

Belmont, 2011, Komunikasi Non Verbal, Jakarta: PT Raja Grafindo Persada.

Cenadi. Chirstine Suharto, Nirmana, 2013 Elemen-Elemen dalam Desain Komuikasi Visual, Jurnal ilmiah.

Crowe, Norman dan Pul Laseau. Van Nostrand Reinbbold, 2013 Visual Notes For Architecs and Designer. New York:.

Dyke, Scott Van, 2011. From Line to Design. Indiana, West Layayette: PDA Publishers Corparatio.

Effendy, Onong Uchjana, 2015. Ilmu Komunikasi, Teori dan Paktek. Bandung. Penerbit PT Remaja Rosdakarya. 
Haise, Albert O. Architectural Rendering, 2011. New York: McGraw-Hill Book Company, Inc.

Hamdan, H. (2019). Wacana dalam Perspektif Norman Fairclough. Jurnal Komodifikasi, Volume 7(1).

Hartmann, Robert R. Graphics for Designers. Iowa, Ames, 2016: The Iowa State University.

Lockard, William Kerby. Design Drawing, 2011. New York: Van Nostrand Reinhold Company.

Mulyana Deddy, 2010, Ilmu Komunikasi suatu pengantar, Bandung: Remaja Rosdakarya.

Moleong, 2010, Research Design Pendekatan Kualitatif, Kuantitatif dan Mixed, (Yogyakarta: Pustaka Pelajar)

Nostrand Reinbold 2012 Drawing As a Means to Architecture. New York: Company.

Penang Merah, 2014, Komunikasi Non Verbal, Yogyakarta: LEFSI.

Rakhmat, 2011, Persepsi dalam Ilmu Komunikasi, Jakarta: PT Raja Grafindo Persada.

SumavorLarry A. dan Richard E. Porter, 2010, Communication Between Culture, Balmont, California: Wadswort.

Tanaka, Eisuke. Architectural Presentation. Tokyo: Graphic-Sha Publishing Co. Ltd, 2010.

Website:

https:/hellosehat.com,/ 2020/hidup-sehat/fakta-unik/peringatan-bahayamerokok, 1 mei

https ://antarnews.com/2020/style/gaya-hidup/ bahaya-merokok, 1 mei https://jakartapost.com/2020/carahidupsehat/bahaya-merokok, 1 mei https://dw.com/lifestyle/ 2020/kehidupan-sehat/bahaya-rokok-pada-kesehatan, 1 mei 